\title{
ЗАВИСИМОСТЬ КЛЮЧЕВЫХ ПОКАЗАТЕЛЕЙ ИНВЕСТИЦИОННЫХ ПРОЕКТОВ ОТ ИХ СТОИМОСТИ НА ПРИМЕРЕ САМАРСКОЙ ОБЛАСТИ
}

\author{
(c) 2019 Левченко Лариса Владимировна \\ кандидат экономических наук, доцент \\ Самарский государственный экономический университет, Россия, Самара \\ E-mail: lvls@mail.ru \\ () 2019 Яковенко Мстислав Дмитриевич \\ магистрант \\ Самарский государственный экономический университет, Россия, Самара
}

Статья посвящена исследованию имеющихся зависимостей ключевых показателей инвестиционных проектов от стоиомсти. Исследование проведено на основании открытых данных Министерства экономического развития и инвестиций Самарской области, Министерства сельского хозяйства и продовольствия Самарской области. Авторами описывается возможность использования настоящего исследования в практических целях, например при принятии решений о выделении денежных средств для государственной поддержки того или иного субъекта.

Ключевые слова: инвестиции, государственные инвестиции, программы господдержки, микрокредитование, корреляция

В условиях современной экономики России, существенная часть которой, так или иначе, контролируется государством, всё большую роль в структуре финансовых рынков играет рынок государственных инвестиций.

Например, исходя из сведений, размещенных на официальном сайте единой информационной системы в сфере закупок [1], в 2019 году общий объем размещения государственного заказа составил более 10 трлн. рублей. Из указанной суммы проблематично выделить точную сумму инвестиций в классическом понимании (закупка оборудования, капитальные вложения и т.п.), однако с уверенностью можно сказать, что государство в любом случае является самым крупным инвестором.

Говоря о фондовом рынке, нельзя не отметить, что согласно данным Министерства финансов Российской Федерации [2], только за 2018 год государство выпустило различные ценные бумаги (ОФЗ, ГСО и т.д.) на общую сумму почти 3 трлн. рублей. При этом по данным Московской фондовой биржи [3] объем размещений облигаций за 2018 год вырос на 28,7\% - до 19,6 трлн. рублей, из которых 8,1 трлн. рублей пришлось на облигации федерального займа (ОФЗ) и ОБР, 2,85 трлн. рублей - на корпоративные и 8,6 трлн. рублей - на однодневные корпоративные облигации.

Необходимо учитывать, что говоря о раз-

мещении государственных ценных бумаг, речь идёт о привлечении инвестиций государством, тогда как при размещении тех или иных заказов, реализации государственных программ, проектов или соглашений в рамках государственно-частного партнерства, речь уже идёт о вложении ресурсов.

Для того, чтобы эффективно использовать государственные инструменты инвестирования, необходимо понятие их сущности; определение места среди прочих составляющих финансового рынка; выявление проблем при использовании таких инструментов; моделирование перспектив развития.

Финансовый рынок, в широком смысле представляет собой соединение международных и национальных рынков. С помощью финансовых специальных финансовых институтов, финансовый рынок выполняет функции по перераспределению и накоплению финансовых ресурсов.

В классическом понимании, финансовый рынок включает в себя: кредитный, валютный, страховой рынки, а также рынок ценных бумаг и рынок инвестиций.

В свою очередь рынок инвестиций можно также поделить на рынок частных инвестиций и рынок государственных инвестиций.

Инвестиционная деятельность определяется как вложение инвестиций, или инвестирование, и совокупность практических действий по реа- 
лизации инвестиций [4].

В Российской Федерации сегодня реализуется целый ряд различных программ, федерального и местного масштаба, связанных с поддержкой предпринимательства.

На первый взгляд, такие действие государства не должны считаться инвестициями, поскольку реальную прибыль от реализации того или иного проекта получит частное лицо. Вместе с тем, по мнению авторов, классические определения инвестиционной деятельности не в достаточной мере отражают суть инвестиционного процесса, поскольку преумножать доходы возможно не только за счет каких-либо материальных благ, но и за счет нематериальных активов, уникальной рабочей силы и т.д. Кроме того в теории инвестиционной деятельности также говориться о том, что конечной целью могут быть не только материальные блага - деньги, имущество и т.д., но и так называемый «полезный эффект».

Создание благоприятного инвестиционного климата является таким полезным эффектом. Более того, в случае успешной реализации проекта, в государстве появится новый активный налогоплательщик, который не только может пополнить бюджет за счет различных налогов и сборов, но также и создать рабочие места, тем самым обеспечивая решение самых разных социальных проблем.

Возвращаясь к типичным инструментам, которые использует государтсво для реализации программ поддержки предпринимательства, следует сказать, что одним из самых вострбованных инструментов является микрокредитование.

На сегодняшний день в Самарской области реализуются десятки инвестиционных проектов, основанные как на частных инвестициях, так и на государственных вложениях. От стоимости проектов зависит в той или иной степени срок окупаемости, уровень прибыли и т.п. показатели. Такие показатели были бы ключевыми в условиях постановки конечной цели только в виде прибыли.

Вместе с тем, государство как особый субъект экономических отношений, зачастую преследует своей целью иные социально-значимые полезные эффекты, по этой причине нередко те или иные инвестиционные проекты реализуются не только исходя из экономической выгоды, но и исходя из, например, создания благодаря инвестиционному проекту той или иной социальной инфраструктуры или условий для дальнейшего развития.

В целях установления корреляции между стоимостью инвестиционных проектов и их ключевыми показателями, авторами проанализировано 44 инвестиционных проекта, реализуемых сегодня в Самарской области [5].

Авторами в качестве отправной точки была взята общая стоимость инвестиционных проектов и исследована её зависимость от:

1) срока реализации проекта;

2) срока окупаемости проекта;

3) количества создаваемых рабочих мест;

4) начиличие/отсутствие собственных денежных средств на старте проекта.

Проведенные с использование специализированного программного обеспечения (Gretl) расчеты показали, что в указанных показателях имеется корреляция со следующими выводами.

При увеличении срока реализации проекта на 1 месяц его цена в среднем возрастает на 3842,22 тыс. рублей

При увеличении срока окупаемости проекта на 1 месяц его цена в среднем возрастает на 652,19 тыс. рублей

При увеличении количества создаваемых рабочих мест его цена в среднем увеличивается на 2466,52 тыс. рублей.

Также была сделан вывод о том, что стоимость инвестиционных проектов на 86,5\% определяется сроком реализации проекта и количеством создаваемых рабочих мест, а на 13,5\% вариацией иных факторов.

При увеличении срока реализации проекта на 1 месяц его стоимость в среднем возрастает на 4,7 млн. рублей

При увеличении количества создаваемых рабочих мест на 1 единицу стоимость инвестиционного проекта в среднем увеличивается на 2,2 млн. рублей.

В заключение, по мнению авторов, следовало также провести анализ значимости наличия/ отсутствия собственных средств при реализации инвестиционных проектов.

Вместе с тем, было выявлено, что наличие собственных средств может только уменьшить стоимость инвестиционного проекта в среднем на 38,2 млн. рублей

Резальтаты настоящего исследования имеют огромное практическое значение для принятия различными государтсвенными институтами 
решений об одобрении того или иного проекта, ния примерного социально-полезного эффекта. поскольку предполагают возможность вычисле-

\section{Библиографический список}

1. https://zakupki.gov.ru/epz/main/public/home.html\#statAnchor

2. https://www.minfin.ru/ru/perfomance/public_debt/internal/operations/data/

3. https://report2018.moex.com/ru/30/20/10

4. Пратьков Д.Ю. Виды инвестиций // Законодательство и экономика. 2014. N4.

5. https://economy.samregion.ru/activity/investicii/itogi_deyatelnosti/investitsionnaya-deyatelnost-v-samarskoyoblasti/ 